\title{
Willingness-to-pay for spectacles studies: a scoping review of rationales and methodologies
}

\section{Christine Graham}

University of KwaZulu-Natal School of Medicine

Ving Fai Chan ( $\sim$ V.Chan@qub.ac.uk)

Queen's University Belfast Centre for Public Health https://orcid.org/0000-0002-4968-7953

\section{Research article}

Keywords: Willingness to pay, spectacles, eyeglasses

Posted Date: January 9th, 2020

DOI: https://doi.org/10.21203/rs.2.20426/v1

License: (1) This work is licensed under a Creative Commons Attribution 4.0 International License. Read Full License 


\section{Abstract}

\section{Background}

The global recognition of uncorrected refractive error as the main cause of vision impairment has increasingly demand for affordable, available and accessible refraction and spectacle dispensing services. Willingness to pay (WTP) for spectacles studies afford context-specific planning for integration of these services into eye care service delivery. The aim of this scoping review was to identify the rationales and the range of methods used when conducting WTP for spectacles studies.

Methods

We undertook this scoping review, using a search from EBSCO (host), Medline, PubMed, SCOPUS, Google Scholar and ProQuest databases. We also searched Google and eyecare organisation's websites for grey literature. We analysed the articles using the scoping review methodological framework proposed by Arskey and Marley.

Results

The search identified 237 from and only 14 were eligible. $79 \%(n=11)$ were published articles and $21 \%(n=3)$ were grey literature. All studies were from developing countries. Most of the studies reported rationales with a few that were vague. The majority of the studies used survey-based techniques, where the limitation and strengths were reported.

\section{Conclusion}

The scoping review highlighted the knowledge gap in reporting the WTP for spectacles methodologies that need to be considered in reporting future research.

Keywords: Willingness to pay, spectacles, eyeglasses

\section{Introduction}

Public health services are recognised as a common good that is beneficial to users in terms of life and, to a certain extent, improved quality of life. However, due to limited available resources, decision-making about new initiatives in public health interventions is increasingly guided by economic evaluation theory [1]. Economic evaluation is rationalised as the comparison of cost and outcomes of health care intervention [2-4]. The supply of a health intervention has to be balanced with its demand. Hence, researchers tend to analyse the consumers' willingness to pay for the intervention to improve or achieve a better health outcome $[4,5]$.

Willingness-to-pay (WTP) analysis is derived from economic evaluation theory, which allows for an understanding of preferences and wishes of individuals and society's overall budget constraint $[6,7]$. This analysis is thus deemed essential to measure the 'strength of preferences' as it will inform decision making by maximising the value of benefits and the integration of the outcomes of these assessments [8]. However, WTP methods have also shown to have several flaws as they are usually conducted in hypothetical situations which can produce inaccurate results [9]. These results can show how participants underestimate or overestimate 
WTP responses according to the environment they are in at the moment [5, 9]. Furthermore, participants may be unaware of the value of the product and since the results depend on how participants value the outcome, this becomes subjective [10]. Finally, it ignores the socio-economic value, leading to discriminatory effects on low income individuals and social groups $[5,6]$.

In general, there are two approaches for determining WTP preferences, and both have been used in WTP for spectacles. They are:

- the stated preferences, which are determined by contingent valuation methods undertaken through surveybased techniques $[1,9]$. The contingent valuations surveys are either direct in terms of participants being asked to state their WTP (designed in a binary response or binary-with-follow-up) for a specified health outcome $[1,10,11]$, or indirectly where participants are asked to state their WTP from a set of options. Both direct and indirect valuations have been considered to have potential biases as most of the time, assessments are conducted in hypothetical situations [8,12].

- The revealed preferences are determined from experiments conducted in real settings with actual products or services with the results obtained from participant's price responses $[9,10,13]$. One technique used is Vickrey Auctions where the participants do the valuation of the product and then each submits a sealed bid [10]. The highest bid will determine the purchase price. Another technique that has been used is Becker-DeGroot-Marschack (BDM) which permits participants to buy the product based on the final sale price which has been randomly drawn from their submitted bids [10].

Willingness-to-pay for spectacles can only be understood in the context of broader eye health developments. For over a decade, the global estimates on visual impairment focussed on elimination of blindness where the leading causes were seen as cataract, trachoma, glaucoma, onchocerciasis and others [14]. These estimates excluded refractive error as a cause of visual impairment leading to 'significantly underestimate the actual burden of uncorrected refractive error [15]. However, notable recognition was the World Health Organisation (WHO) press release of the global data of uncorrected refractive error announced on the 2006 World Sight Day. The data revealed that 153 million people worldwide have uncorrected refractive errors which can certainly be corrected with spectacles, 'yet millions of people in low and middle income countries do not have access to these basic services' [16].

It was consequently acknowledged that cataract and uncorrected refractive error were the biggest causes of visual impairment and confirmed the latter as a matter of public health concern $[17,18]$. Nonetheless, there is not much evidence of WTP in eye health and most of the studies have been conducted for cataract surgery [19-21]. Despite uncorrected refractive error being the leading cause of vision impairment and spectacle correction being a cost-effective management, few studies have been conducted to determine the WTP for spectacles. The lack of studies determining the WTP for spectacles can be explained by the belated recognition of uncorrected refractive error as a public health issue and the provision of spectacles services being primarily in private settings.

To achieve effective investments in the reduction of uncorrected refractive error, a self-sustaining system that has a competent eye health workforce and provision of spectacle correction according to needs would be required [22]. However, lack of screening and the accessibility and affordability of refractive services hinders the provision of needs. Even where services are available compliance remains low due to either costs or 
cultural barriers [17]. Accordingly, WTP for spectacles has been seen as an appropriate measure to address the aforementioned issues and for planning for integration into eye care services. This scoping review does not report and compares the results of the WTP for spectacles in the selected studies because the results are context-specific in terms of external and internal influences. Instead, we aim to describe the range of methodologies used and the defined rationales in conducting studies of WTP for spectacles.

\section{Methods}

We searched the PROSPERO database for any previous reviews of WTP for spectacles as the initial step in conducting this scoping review and found none. The need to identify the rationales and methods used to conduct WTP for spectacles [23], obliged us to conduct this scoping review as the body of literature is so small (many are related to programme development) that we might lose important information by excluding grey literature.

The scoping review employed the methodological framework proposed by Arskey and Marley [24], which was further elaborated by Levac et al., [25]. This framework is comprised of five stages; 1 ) identifying the research question, 2) identifying relevant studies, 3) study selection, 4) charting the data and 5) collating, summarising and reporting the results.

Research question

Identifying the research question as the first step in conducting a scoping review is significant as it provides direction as to how search strategies are developed [24]. The research team defined the research question as: "What is the existing knowledge in the literature about willingness-to-pay for spectacles?" Initially, the question sounded quite broad. However, the intended outcome of the study guided our scope of inquiry [25] to include the mapping of the methodology used and their justifications in conducting the studies.

\section{Search Strategy}

The search strategy was undertaken in June 2019 to capture all relevant literature in several electronic databases, which included EBSCO (host), Medline, PubMed, SCOPUS, Google Scholar and ProQuest. To achieve precision and recall in the results, a search strategy was conducted using the following specific keywords: "willingness-to-pay" and "spectacles". We extended the term "spectacles" to a related word, "eyeglasses". By using MeSH and Boolean operators, we sought the search terms in either the title, abstract or full text. We also searched Google and eyecare organisation's websites for grey literature (non-peer-reviewed literature or unpublished reports).

\section{Study Selection}

The selection of available literature was undertaken systematically. The reviewer first searched databases for keywords based on the inclusion and exclusion criteria. We included all published and unpublished research articles, reports and any related documents which assessed willingness-to-pay, spectacles or eyeglasses in the review. We excluded all duplicate articles, reports and documents that were not reported in English and all research articles that combined willingness-to-pay for other eye health issues such as spectacles after cataract 
surgery and the provision of eye health services were excluded. When uncertain about a document, the reviewer kept the article and discussed with the second reviewer.

\section{Charting the data}

We developed a data charting template from a Microsoft word formatted table to capture all the selected studies. In this standardised form we extracted the following details from the articles; year, country, study design, unit of study, sample, outcome measure and rationale, methods, findings, limitations, strengths and recommendations. Two members of the research team independently extracted data of the included studies and later met to determine whether the captured studies were aligned to the research question [25]. The whole process was iterative with the researchers updating the data charting template constantly. We resolved any disagreements by compromising and accommodating through discussion and consensus.

Collating, summarising and reporting

We presented the collated information obtained from the studies in three categories. Firstly, we organised the studies based on their reported study rationale, counted them with their percentages. Secondly, we organised the studies according to the methods used in terms of characteristics of participants, sampling strategies and tools used for data collection. Thirdly, we organised the studies according to their identified strengths and limitations. Since we intended to explore the scope of knowledge in these three categories regarding willingness-to-pay for spectacles, we summarised information as presented across articles.

\section{Results}

\section{Literature search}

Figure 1 outlines the results of the search strategy and study selection processes. Since, a variety of disciplinary perspectives (economics, business, marketing and others) used the willingness-to-pay concept, the search process from several databases produced many irrelevant articles. We, therefore, limited a selection to the first 50 articles and identified 252 articles through all defined searches. Using the eligibility criteria, we condensed the number to 14 articles.

\section{Characteristics of the studies}

In this scoping review, we located 14 articles regarding WTP for spectacles with eleven articles published (79\%) in journals, and the other three (21\%) were internet documents. One was a preprint article, and two were reports from non-governmental organisations (One-Dollar-Glasses [ODG] and Sight Savers in collaboration with Seeing is Believing).

The reported rationale of the studies

The reported rationales for the WTP assessment in these studies were 1) to understand potential pathways of spectacle provision and planning for eyecare service delivery [26-31], 2) initiated by low levels of spectacle acceptance [32], 3) to construct a business model [33] and 4) to improve outreach refraction and spectacle 
dispensing services $[34,35]$. In some studies, the rationale was unclear as WTP for spectacles was a small component of a bigger study. The reported rationale of the WTP studies is shown in Table 1.

Table 1. Study rationale for conducting a willingness-to-pay study $(n=14)$

\begin{tabular}{|c|c|c|}
\hline Rationale & $\begin{array}{l}\text { No. of } \\
\text { studies }\end{array}$ & Percentage \\
\hline $\begin{array}{l}\text { To understand the demand and potential pathways of spectacles provision to } \\
\text { improve eye care services }\end{array}$ & 4 & $29 \%$ \\
\hline Limited or no information available for planning of spectacle service & 2 & $14 \%$ \\
\hline Low levels of spectacle acceptance & 1 & $7 \%$ \\
\hline A need to construct a business model & 1 & $7 \%$ \\
\hline Improve outreach refraction and spectacle dispensing services & 2 & $14 \%$ \\
\hline None reported & 4 & $29 \%$ \\
\hline
\end{tabular}

The reported methodologies from eligible studies

The general WTP methodology used in the 13 selected articles was the survey-based techniques which establish stated preferences. These techniques used a contingent valuation approach with binary/dichotomous and binary-with-follow-up questions, and included indirect surveys with more choices where the minimum and maximum prices are available to the participants. Table 2 shows the methodologies used in the selected articles. 
Table 2

The methodology of willingness-to-pay studies

\begin{tabular}{|c|c|c|c|c|}
\hline Year & Country & Participants/n & $\begin{array}{l}\text { Calculated sample size } \\
\text { /determination }\end{array}$ & $\begin{array}{l}\text { Tools for data } \\
\text { collection }\end{array}$ \\
\hline 2007 & Timor-Leste & $\begin{array}{l}\text { *Adults } \\
\geq 40 \text { years/ } \\
1414\end{array}$ & $\begin{array}{l}1470 \text { / systematic random } \\
\text { sampling/cluster sampling }\end{array}$ & $\begin{array}{l}\text { Survey } \\
\text { Face to face interview }\end{array}$ \\
\hline 2008 & Cambodia & $\begin{array}{l}\text { *People } \\
\text { prescribed } \\
\text { spectacles / } \\
252\end{array}$ & $\star 293$ / not specified & $\begin{array}{l}\text { Interview - } \\
\text { questionnaire } \\
\text {-Binary-with-follow-up } \\
\text { (BWFU) technique }\end{array}$ \\
\hline 2008 & Fiji & $\begin{array}{l}\text { *Households } \\
\text { individuals / } \\
174\end{array}$ & $\begin{array}{l}174 \text { / systematic random } \\
\text { sampling }\end{array}$ & $\begin{array}{l}\text { A rapid appraisal } \\
\text { technique - semi- } \\
\text { structured interviews } \\
\text {-WTP determined - } \\
\text { five-choice modified } \\
\text { payment card }\end{array}$ \\
\hline 2008 & China & $\begin{array}{l}{ }^{*} \text { Children - } \\
\text { junior high } \\
\text { school / } 674\end{array}$ & $\begin{array}{l}2100 / \text { cluster-based random } \\
\text { sampling }\end{array}$ & $\begin{array}{l}\text { Interview - } \\
\text { questionnaire }\end{array}$ \\
\hline 2009 & Timor-Leste & $\begin{array}{l}\text { *Adults } \\
\geq 35 \text { years / } \\
152\end{array}$ & $\begin{array}{l}168 \text { / a prevalence of stated WTP } \\
\text { U\$0.10 of } 75 \% \pm 10 \% \text {, at } 5 \% \text { level of } \\
\text { significance, cluster design effect } \\
\text { of } 2.0 \text {, assuming a } 15 \% \text { non- } \\
\text { response rate }\end{array}$ & $\begin{array}{l}\text { Survey - } \\
\text { Questionnaire } \\
\text {-Binary-with-follow-up } \\
\text { technique }\end{array}$ \\
\hline 2010 & Tanzania & $\begin{array}{l}{ }^{*} \text { Adults } \\
\geq 40 \text { years of } \\
\text { age } / 323\end{array}$ & $\begin{array}{l}400 / \text { estimated prevalence of } \\
61.7 \% \text {-precision - } 5 \% \text { and } 95 \% \\
\text { confidence level }\end{array}$ & $\begin{array}{l}\text { Interviews } \\
\text { *open question }\end{array}$ \\
\hline 2012 & Timor-Leste & $\begin{array}{l}\text { *Adults } \\
\geq 40 \text { years / } \\
1974\end{array}$ & $\begin{array}{l}2250 \text { / cluster random sampling; } \\
\text { precision } \pm 1.5 \% \text { ( } 20 \% \text { relative } \\
\text { difference), with } 95 \% \text { confidence, a } \\
\text { design effect of } 1.6 \text {, a response } \\
\text { rate of } 80 \%\end{array}$ & $\begin{array}{l}\text { Survey - Interview - } \\
\text { questionnaire }\end{array}$ \\
\hline 2013 & Nicaragua & $\begin{array}{l}\text { *Adults } \\
\geq 34 \text { years / } \\
353\end{array}$ & 353 / sample from the records & Retrospective review \\
\hline 2015 & $\begin{array}{l}\text { Papua New } \\
\text { Guinea }\end{array}$ & $\begin{array}{l}\text { * Individuals } \\
(16-96 \text { years }) \\
\text { / } 614\end{array}$ & 614 / convenience sampling & $\begin{array}{l}\text { Interview - } \\
\text { questionnaire }\end{array}$ \\
\hline
\end{tabular}




\begin{tabular}{|c|c|c|c|c|}
\hline Year & Country & Participants/n & $\begin{array}{l}\text { Calculated sample size } \\
\text { /determination }\end{array}$ & $\begin{array}{l}\text { Tools for data } \\
\text { collection }\end{array}$ \\
\hline 2015 & Bangladesh & $\begin{array}{l}\text { * households } \\
\text { / } 1600 \\
\text { *individuals } \\
\text { /558 }\end{array}$ & $\begin{array}{l}\text { * } 1600 \text { household randomly } \\
\text { selected } \\
\text { *558 / randomly selected - } \\
\text { diagnosed with refractive error }\end{array}$ & $\begin{array}{l}\text { *Household survey } \\
\text { *Patient exit } \\
\text { Interviews (eye care } \\
\text { facilities and optic } \\
\text { shop) - Contingent } \\
\text { valuation method } \\
\text { (CVM) } \\
\text {-Triple-bounded } \\
\text { format consists of } \\
\text { dichotomous choice } \\
\text { design }\end{array}$ \\
\hline 2016 & Nigeria & $\begin{array}{l}\text { * Presbyopic } \\
\text { Adults } \\
\geq 40 \text { years / } \\
52\end{array}$ & $\begin{array}{l}600 \text { / cluster random sampling } \\
\text { using probability proportion-to-size }\end{array}$ & Survey - interviews \\
\hline 2017 & $\begin{array}{l}\text { China, India, } \\
\text { Eritrea, Mexico, } \\
\text { Vietnam, } \\
\text { Ecuador, } \\
\text { Guatemala, } \\
\text { Paraguay }\end{array}$ & $\begin{array}{l}\text { Adults } \\
\geq 30 \text { years / } \\
1909\end{array}$ & *Not specified & $\begin{array}{l}\text { Not mentioned but } \\
\text { most probably } \\
\text { through interviews }\end{array}$ \\
\hline 2018 & Ethiopia & $\begin{array}{l}\text { *presbyopic } \\
\text { adults - age } \\
35-73 / 322\end{array}$ & $\begin{array}{l}* 340 / \text { simple random sampling - } \\
\text { single proportion formula }-p= \\
82.9 \% \text { and } 4 \% \text { margin of error }\end{array}$ & $\begin{array}{l}\text { Interviews - } \\
\text { Questionnaire }\end{array}$ \\
\hline 2018 & Burkina Faso & $\begin{array}{l}\text { *persons } \\
\text { prescribed } \\
\text { glasses / } 412\end{array}$ & * 412 / self- select - not clear & $\begin{array}{l}\text { Beck-DeGroot- } \\
\text { Marschack (BDM) } \\
\text { approach - Bidding } \\
\text { 1. participants price } \\
\text { WTP } \\
\text { 2. auction at market } \\
\text { price }\end{array}$ \\
\hline
\end{tabular}

Limitations, strengths and recommendations

Although several studies did not report any WTP technique limitations [30, 32, 36], some reported general survey biases such as recall bias and selection bias [27, 29, 35, 37]. Only one study reported WTP using BDM technique with follow-up questions [31]. The studies reported a variety of limitations, strengths and recommendations on the methodology used, as shown in Table 3 below. 
Table 3

Limitations, strengths and recommendations of included studies

\begin{tabular}{|c|c|c|c|c|}
\hline Year & Country & Limitations & Strengths & Recommendations \\
\hline 2007 & Timor-Leste & $\begin{array}{l}\text { *Weaknesses of rapid } \\
\text { assessment methods } \\
\text { *Not determining maximum } \\
\text { WTP for spectacles }\end{array}$ & *none reported & *None reported \\
\hline 2008 & Cambodia & $\begin{array}{l}\text { *Selection of starting price } \\
\text { with Binary-with-follow-up } \\
\text { (BWFU) may potentially } \\
\text { introduce bias } \\
\text { *Reliability of WTP may be } \\
\text { affected as spectacles } \\
\text { have not demonstrated } \\
\text { significance or minimal } \\
\text { perceived-need to the } \\
\text { respondent } \\
\text { *Future WTP may alter } \\
\text { intentions of first-time } \\
\text { buyers and may not aligned } \\
\text { with the assumptions of } \\
\text { the study } \\
\text { *WTP may not be an } \\
\text { accurate predictor of actual } \\
\text { WTP due to changes in } \\
\text { individual circumstances }\end{array}$ & $\begin{array}{l}\text { *BWFU is an } \\
\text { appropriate technique } \\
\text { as it reduces the range } \\
\text { within which } \\
\text { respondents } \\
\text { measured WTP }\end{array}$ & *None reported \\
\hline 2008 & Fiji & $\begin{array}{l}{ }^{*} \text { Recall bias - the sampling } \\
\text { unit was at a household } \\
\text { level. Hence responses } \\
\text { might be from individuals } \\
\text { that were not involved in } \\
\text { the issues asked }\end{array}$ & $\begin{array}{l}\text { *The methodology } \\
\text { used was useful for } \\
\text { planning purposes } \\
\text { and investigation of } \\
\text { anticipated behaviour } \\
\text { in the community }\end{array}$ & $\begin{array}{l}\text { *Further investigations to } \\
\text { ascertain the maximum } \\
\text { price each individual is } \\
\text { willing to pay for } \\
\text { spectacles to enhance } \\
\text { financial equity }\end{array}$ \\
\hline 2008 & China & $\begin{array}{l}\text { *WTP for spectacles was } \\
\text { assessed by children aged } \\
13 \text { to } 17 \text { - the validity of } \\
\text { such data may be } \\
\text { questionable } \\
\text { *Unable to conclude with } \\
\text { certainty that any families } \\
\text { purchasing spectacles did } \\
\text { so as a result of the } \\
\text { intervention }\end{array}$ & *None reported & $\begin{array}{l}{ }^{*} \text { A randomised trial will } \\
\text { address the limitations of } \\
\text { the study }\end{array}$ \\
\hline 2009 & Timor-Leste & $\begin{array}{l}\text { *WTP may overestimate } \\
\text { actual WTP }\end{array}$ & $\begin{array}{l}\text { *BWFU good to be } \\
\text { utilised as a predictor } \\
\text { of behaviour }\end{array}$ & $\begin{array}{l}\text { *BWFU likely to be used } \\
\text { for the planning of } \\
\text { spectacle provision by eye } \\
\text { care programmes in other } \\
\text { countries }\end{array}$ \\
\hline 2010 & Tanzania & $\begin{array}{l}\text { *Difficulty in recruiting } \\
\text { individuals aged } 40- \\
50 \text { years } \\
\text { * Responder bias - aware of } \\
\text { receiving free spectacles }\end{array}$ & *None specified & $\begin{array}{l}\text { *Further research -an } \\
\text { assessment of tiered } \\
\text { payment with cross- } \\
\text { subsidies and } \\
\text { assessment of the wider } \\
\text { community benefits. }\end{array}$ \\
\hline
\end{tabular}




\begin{tabular}{|c|c|c|c|c|}
\hline Year & Country & Limitations & Strengths & Recommendations \\
\hline 2012 & Timor-Leste & None reported & *None reported & *None reported \\
\hline 2013 & Nicaragua & $\begin{array}{l}\text { *WTP scale had fewer } \\
\text { choices on the lower end of } \\
\text { the scale } \\
\text { *Likely response biased - } \\
\text { due to free glasses }\end{array}$ & *None reported & $\begin{array}{l}\text { *Questions relating to } \\
\text { WTP for replacement } \\
\text { should be modified to a } \\
\text { lower scale or perhaps } \\
\text { changed to the binary- } \\
\text { with-follow-up method }\end{array}$ \\
\hline 2015 & $\begin{array}{l}\text { Papua New } \\
\text { Guinea }\end{array}$ & $\begin{array}{l}\text { *Likely selection bias as } \\
\text { convenience sampling was } \\
\text { used hence sample may } \\
\text { not be representative } \\
\text { *Test-retest was not } \\
\text { undertaken, thus unable to } \\
\text { report the stability } \\
\text { *The questionnaire was not } \\
\text { translated to the diverse } \\
\text { local languages. The } \\
\text { survey was conducted } \\
\text { verbally. }\end{array}$ & $\begin{array}{l}\text { *The development of } \\
\text { the questionnaire } \\
\text { included ideas for } \\
\text { focus groups and eye } \\
\text { health workers }\end{array}$ & *None reported \\
\hline 2016 & Nigeria & $\begin{array}{l}\text { *Participants awareness } \\
\text { that they might receive free } \\
\text { spectacles might have } \\
\text { influenced their responses }\end{array}$ & *None reported & *None reported \\
\hline 2017 & $\begin{array}{l}\text { China, } \\
\text { India, } \\
\text { Eritrea, } \\
\text { Mexico, } \\
\text { Vietnam, } \\
\text { Ecuador, } \\
\text { Guatemala, } \\
\text { Paraguay }\end{array}$ & $\begin{array}{l}\text { * Likely an underestimate of } \\
\text { WTP for spectacles } \\
\text { estimate to the actual price } \\
\text { paid for glasses }\end{array}$ & * A large sample size & *None reported \\
\hline 2015 & Bangladesh & *None reported & $\begin{array}{l}\text { *Contingent valuation } \\
\text { method with } \\
\text { simulation of } \\
\text { refractive error } \\
\text { appears to produce } \\
\text { reliable and valid WTP } \\
\text { estimates }\end{array}$ & *None reported \\
\hline 2018 & Ethiopia & $\begin{array}{l}\text { * Likely response bias thus } \\
\text { many not guarantee valid } \\
\text { responses } \\
\text { *Outreach services might } \\
\text { have inflated spectacle } \\
\text { coverage and likely to } \\
\text { increase the proportion of } \\
\text { WTP }\end{array}$ & *None reported & *None reported \\
\hline
\end{tabular}




\begin{tabular}{|c|c|c|c|c|}
\hline Year & Country & Limitations & Strengths & Recommendations \\
\hline 2018 & $\begin{array}{l}\text { Burkina } \\
\text { Faso }\end{array}$ & $\begin{array}{l}\text { *The BDM is too complex } \\
\text { to understand }\end{array}$ & $\begin{array}{l}\text { *The Becker-DeGroot- } \\
\text { Marschak (BDM) } \\
\text { confronts the person } \\
\text { with a real purchase } \\
\text { decision } \\
\text { *BDM allows } \\
\text { observing the exact } \\
\text { price of WTP } \\
\text { *BDM allows drawing } \\
\text { a detailed demand } \\
\text { curve } \\
\text { *BDM incentivise } \\
\text { truthful responses } \\
\text { *BDM approach } \\
\text { prevents conflicts } \\
\text { between bidders }\end{array}$ & *None reported \\
\hline
\end{tabular}

\section{Discussion}

The literature search identified 237 articles of which 14 were eligible for this scoping review. $79 \%(n=11)$ of these articles were published and $21 \%(n=3)$ were grey literature. All studies were from developing countries. Most of the studies reported rationales with a few that were vague. The majority of the studies used surveybased techniques, where the limitation and strengths were reported.

Our scoping review showed that very little had been researched into WTP for spectacles despite the global burden of uncorrected refractive errors. Perhaps the fairly recent recognition as a public health issue that included visual impairment caused by uncorrected refractive errors into VISION 2020 global initiative of elimination of avoidable blindness [38] explains why the scoping review found the earliest published article in 2007. Additionally, all the studies undertaken were mainly from developing countries because low socioeconomic status is one of the risk factors of visually impairment - socio economic status that affects $90 \%$ of vision impaired people live in developing countries [38]. Although the justification of using certain methods in research is considered to be essential [39], little is reported on the pros and cons of WTP for spectacles methodology.

The reported rationale of WTP analysis for spectacles in the eligible studies

As mentioned previously, WTP is a cost-and-benefit measure. The rationale for WTP analysis in health care is due to the financial dilemma inherent in all service delivery. In developing countries, health services are paid out of pocket, and WTP assessment ascertains the potential for cost recovery and the demand for service delivery of a specific health issue [40-42]. Accordingly, the assessments are viewed as a premise for financial sustainability and development of cross-subsidisation procedures that allows for equity, affordability, accessibility, availability and quality $[43,44]$. Our scoping review found a similar rationale in several of the eligible studies in terms of understanding the demand through participant's preferences that could facilitate the provision of affordable and accessible spectacle services [26-31, 33, 34].

Similarly, another study defined its rationale in terms of improving the quality of spectacle delivery [32]. Further, in most of the eligible studies in this scoping review, WTP for spectacles was reported as a small component of 
a bigger study of eye care service delivery. Hence, the rationale for conducting a WTP analysis was not mentioned. It is clear, however, that the rationale to undertake these studies was to improve refraction services, spectacle dispensing and financial sustainability.

\section{Methodologies}

The scoping review has demonstrated how the eligible studies reported their methods in terms of study participants, sampling method and sample size calculation in the assessment of WTP for spectacles. Most of the participants in the selected studies were adults due to the 2004 estimated prevalence of uncorrected refractive errors which was $2.43 \%$ for people aged $40-49$ years and $7.83 \%$ for people aged 50 and above [17].

Regarding sampling methods the majority of studies used probability sampling which comprised of simple random sampling [28, 30, 35], systematic sampling [26, 27] and cluster sampling [32, 33, 36, 45]. All are advantageous as simple random sampling is usually representative $s$ of the general population, systematic sampling spreads the sample evenly over the population and cluster sampling is economical and feasible for larger populations [46]. Although there are various disadvantages, probability sampling is still appropriate as there is a possibility for each individual to be selected in the study.

Conducting sample size determination is a pre-requisite step in the study design to enable researchers to make inferences about the wider study population. In reporting the sample size determination adequately allows for a study to be conducted on a defined sample size that leads to the precision of estimates and a power of the results $[47,48]$. It simply means that an appropriate sample size will yield precise and accurate conclusions. Our scoping review found only four studies that reported sample size determination $[28,33,35,36]$. Since most of the studies did not report the sample size determination, the interpretation of these studies [26, 27, 29-32, 34] needs to be approached with caution. Further, the replication of these studies will be problematic as the methodology is not explicit.

Limitations, strengths and recommendations

Although several studies did not report any WTP technique shortcomings [30,32, 35, 36], some reported general survey biases such as recall bias and selection bias [27]. In light of these limitations, WTP does not enforce restrictions on the scope of benefits in which participants are allowed to express their preferences [6]. All preferences are observed as appropriate for WTP results, both beneficial and the non-beneficial.

Criticism of stated preferences techniques are mainly based on hypothetical situations where studies are undertaken, leading to a hypothetical bias $[4,12]$. It is claimed that the dichotomous nature of the questions, comprising a defined price and choice on a pre-defined set of prices, may lead participant's to overestimate the responses of WTP depending on the environment or conditions at the time $[4,9,49]$. It is possible, however, to remove hypothetical bias by a follow-up certainty question, which may result in realistic WTP [12]. While 13 studies in this scoping review were conducted in similar hypothetical conditions most did not report this shortcoming while others explicitly stated the overestimation and underestimation of WTP $[28,33,34,45,50]$. It is thus unclear whether these flaws were observed in any of the included studies.

Alternatively, WTP studies expected to address hypothetical biases used revealed preferences techniques such as BDM as it estimates WTP in real settings of the phenomenon of study. Elicitation of WTP using BDM is 
claimed to be incentive-compatible as the distribution of maximum prices is offered by the participants $[9,10]$. Participant WTP that is greater than or equal to the randomly determined price must pay for the product. BDM similar to survey techniques is vulnerable to strategic bias, which affects WTP in terms of overestimation or underestimation [49]. Hence, it has been stated that efforts to employ different techniques to correct WTP estimate may reduce bias but not eliminate it [5]. Wertenbroch and Skiera stated that the BDM technique is realistic, transparent to participants, operationally efficient in terms of time, cost and effort to conduct [10]. Only one study reported WTP using BDM technique with follow-up questions [31]. The follow-up questions seem to validate the estimated WTP as participants express their satisfaction with the product [9]. The selected studies of this review concurred with most of the pros of BDM method, such as being realistic and incentivising truthful responses [31]. However, it also claimed that it was too complex to understand during implementation. The incentive of BDM has been seen as irrelevant as the determined sale price is not independent of distribution prices [51].

This scoping review is instructive for the future of WTP for spectacles as it has highlighted the strengths and weaknesses of reporting research methods which may be deemed necessary in guiding future research. However, studies were searched in the English language only, which might demonstrate its limitation. Further, despite our attempt to search published and grey literature on databases, webpages and others as well as not having contacted researchers for further identification, we might have missed some studies during the process.

\section{Conclusion}

This scoping review has identified several studies that have estimated WTP for spectacles. These studies have pursued survey-based and experiment techniques to estimate WTP. The scoping review highlighted the gaps in the way of presenting these methodologies that need to be considered in reporting future research.

\section{Abbreviations}

BDM

Becker DeGroot-Marschack

WTP

Willingness to pay

WHO

World Health Organisation

\section{Declarations}

\section{Ethics approval and consent to participate}

Not applicable

\section{Consent to publish}

Not applicable

\section{Availability of data materials}


All data generated during the study can be found in the supplementary information files and some are included in the study.

\section{Competing Interest}

The authors have no competing interest.

\section{Funding}

The study is funded by the Department for Economy Global Challenge Research Fund. The funder has no contribution in design of the study and collection, analysis and interpretation of data and in writing of the manuscript.

\section{Authors Contribution}

CG: Contributed in conceptualising the idea, literature search and data analysis, drafting the manuscript and provided the final approval. VFC: Conceptualised the idea, contribution in literature search, critical review on the manuscript and provided final approval.

\section{Acknowledgement}

None

\section{References}

1. Ryen L, Svensson M. The willingness to pay for a quality adjusted life year: A review of the empirical literature. Health Econ [Internet]. 2015;24:1289-301. Available from: www.wileyonlinelibrary.com

2. Richardson J. Economic evaluation of health promotion: Friend of foe? Aust N Z J Public Health. 1998;22(2):247-53.

3. Goodacre S, McCabe C. An introduction to economic evaluation. Emerg Med J. 2002;19:198-201.

4. Cookson R. Willingness to pay methods in health care: a sceptical view. Health Econ [Internet]. 2003;12:891-4. Available from: http://www.interscience.wiley.com

5. Quevedo JFM, Hernandez IC, Espinosa JG, Escudero GS. The willingness-to-pay concept in question. Rev Saude Publica [Internet]. 2009;43(2):352-8. Available from: http://www.scielo.br/pdf/rsp/v43n2/en_7156.pdf

6. Olsen JA, Smith RD. Theory versus practice: A review of "willingness-to-pay" in health and health care. Health Econ. 2001;10(1):39-52.

7. Baker R, Chilton S, Donaldson C, Jones-Lee M, Lancsar E, Mason H, et al. Searchers vs surveyors in estimating the monetary value of a QALY: resolving a nasty dilemma for NICE. Health Econ Policy Law. 2011;6(4):435-47.

8. Donaldson C. Eliciting patients' values by use of "willingness to pay": Letting the theory drive the method. Heal Expect. 2001;4(3):180-8.

9. Breidert C, Hahsler M, Reutterer T. A review of methods for measuring for willingness-to-pay. Innov Mark [Internet]. 2006;2(4). Available from: https://www.semanticscholar.org/paper/A-Review-of-Methods-for- 
Measuring-Breidert-Hahsler/252507925110a2957430d65b074b97f54f47d13b

10. Wertenbroch K, Skiera B. Measuring consumers' willingness to pay at the point of purchase. J Mark Res. 2002;39(2):228-41.

11. Mitchell RC, Carson RT. Using Surveys to Value Public Goods. Resource for the future. Washington, D.C.: Resources for the Future; 1989.

12. Blumenschein K, Blomquist GC, Johannesson M, Horn N, Freeman P. Eliciting willingness to pay without bias: Evidence from a field experiment. Econ J. 2008;118(525):114-37.

13. Ali S, Ronaldson S. Ordinal preference elicitation methods in health economics and health services research: using discrete choice experiments and ranking methods. Br Med Bull [Internet]. 2012 Sep 1 [cited 2019 Sep 23];103(1):21-44. Available from: https://academic.oup.com/bmb/articlelookup/doi/10.1093/bmb/lds020

14. Thylefors B, Negrel AD, Pararajasegaram R, Dadzie KY. Global data on blindness. Bull World Health Organ [Internet]. 1995;73(1):115-21. Available from: https://www.ncbi.nlm.nih.gov/pmc/articles/PMC2486591/

15. Resnikoff S, Pascolini D, Etya'ale D, Kocur I, Pararajasegaram R, Pokharel GP, et al. Global data on visual impairment in the year 2002. Bull World Health Organ [Internet]. 2004 [cited 2019 Sep 16];82(11):844-51. Available from: https://www.who.int/bulletin/volumes/82/11/en/844.pdf

16. WHO. Sight test and glasses could dramatically improve the lives of 150 million people with poor vision [Internet]. WHO Media Centre. World Health Organization; 2006 [cited 2019 Sep 11]. Available from: https://www.who.int/mediacentre/news/releases/2006/pr55/en/

17. Resnikoff S, Pascolini D, Mariotti SP, Pokharel GP. Global magnitude of visual impairment caused by uncorrected refractive errors in 2004. Bull World Health Organ. 2008;86(1):63-70.

18. Sabanayagam C, Cheng CY. Global causes of vision loss in 2015: are we on track to achieve the Vision 2020 target? Lancet Glob Heal [Internet]. 2017;5(12):e1164-5. Available from:

http://dx.doi.org/10.1016/S2214-109X(17)30412-6

19. He M, Chan V, Baruwa E, Gilbert D, Frick KD, Congdon N. Willingness to Pay for Cataract Surgery in Rural Southern China. Ophthalmology. 2007;114(3):411-6.

20. Geneau R, Massae P, Courtright P, Lewallen S. Using qualitative methods to understand the determinants of patients' willingness to pay for cataract surgery: A study in Tanzania. Soc Sci Med. 2008;66(3):558-68.

21. Ibrahim N, Ramke J, Pozo-Martin F, Gilbert CE. Willingness to pay for cataract surgery is much lower than actual costs in Zamfara State, northern Nigeria. Ophthalmic Epidemiol [Internet]. 2017;25(3):227-33. Available from: http://researchonline.lshtm.ac.uk/4645577

22. Holden BA, Resnikoff S. The Role of Optometry in Vision 2020. J Community Eye Heal [Internet]. 2002;15(44):60-1. Available from: http://www.jceh.co.uk

23. Munn Z, Peters MDJ, Stern C, Tufanaru C, Mcarthur A, Aromataris E. Systematic review or scoping review? Guidance for authors when choosing between a systematic or scoping review approach. [cited 2019 Oct 28]; Available from: https://doi.org/10.1186/s12874-018-0611-x

24. Arksey H, Malley LO. Scoping studies: Towards a methodological Framework. Int J Soc Res Methodol [Internet]. 2005;8(1):19-32. Available from: http://journalsonline.tandf.co.uk/ 
25. Levac D, Colquhoun H, Brien KKO. Scoping studies: advancing the methodology. Implement Sci [Internet]. 2010;5(69):1-9. Available from: https://www.ncbi.nlm.nih.gov/pmc/articles/PMC2954944/

26. Ramke J, Du Toit R, Palagyi A, Brian G, Naduvilath T. Correction of refractive error and presbyopia in TimorLeste. Br J Ophthalmol. 2007;91(7):860-6.

27. Du Toit R, Ramke J, Palagyi A, Brian G. Spectacles in Fiji: Need, acquisition, use and willingness to pay. Clin Exp Optom. 2008;91(6):538-44.

28. Laviers HR, Omar F, Jecha H, Kassim G, Gilbert C. Presbyopic spectacle coverage, willingness to pay for near correction, and the impact of correcting uncorrected presbyopia in adults in Zanzibar, East Africa. Investig Ophthalmol Vis Sci. 2010;51(2):1234-41.

29. Burnett A, Yu M, Paudel P, Naduvilath T, Fricke TR, Hani Y, et al. Perceptions of Eye Health and Eye Health Services among Adults Attending Outreach Eye Care Clinics in Papua New Guinea. Ophthalmic Epidemiol. 2015;22(6):361-9.

30. Sarker M, Rabbani A, Engels T, Gayen P, Islam muhammed N, Hossain S. Understanding demand and provision of eye care services among slum-dwellers in Bangladesh [Internet]. 2015. p. 1-74. Available from: https://www.iapb.org/wp-content/uploads/Bangladesh-Report_final-version_02-06-2015.pdf

31. Grimm M, Hartwig R, Schiessl F. Eliciting the Willingness to Pay ( WTP) for Glasses in Rural Burkina Faso - Final Report - [Internet]. 2018. Available from: https://www.wiwi.uni-

passau.de/fileadmin/dokumente/lehrstuehle/grimm/Publikationen/ODG_WTP_Report_final_Jan_2018.pdf

32. Li L, Song Y, Liu X, Lu B, Choi K, Lam DSC, et al. Spectacle acceptance among secondary school students in rural China: The Xichang Pediatric Refractive Error Study (X-PRES) - Report 5. Investig Ophthalmol Vis Sci. 2008;49(7):2895-902.

33. Ramke J, Palagyi A, Du Toit R, Brian G. Stated and actual willingness to pay for spectacles in timor-leste. Ophthalmic Epidemiol. 2009;16(4):224-30.

34. Ramke J, Palagyi A, Du Toit R, Brian G. Using assessment of willingness to pay to improve a Cambodian spectacle service. Br J Ophthalmol. 2008;92(2):170-4.

35. Alemu HW. Willingness to pay for spectacle among presbyopic population in South Gondar, Ethiopia: A cross-sectional study [Internet]. 2018. Available from: https://www.biorxiv.org/content/10.1101/482943v1

36. Ramke J, Brian G, Naduvilath T. Refractive error and presbyopia in timor-leste: The impact of 5 years of a national spectacle program. Investig Ophthalmol Vis Sci. 2012;53(1):434-9.

37. Hookway LA, Fuhr P, Frazier M. Use of ready-made spectacles to meet visual needs in a low-resource adult population. Optom Vis Sci. 2013;90(5):494-500.

38. World Health Organization. Global Initiative for the Elimination of Avoidable Blindness: action plan 20062011 [Internet]. Geneva: World Health Organization; 2007 [cited 2019 Oct 3]. Available from: https://apps.who.int/iris/handle/10665/43754

39. Meadows KA. So you want to do research? 6: Reporting research. Br J Community Nurs [Internet]. 2004;9(1):37-41. Available from:

https://pdfs.semanticscholar.org/57fc/873f3ea3ed6d86f494189cfdb764ecb957c1.pdf

40. Prata N, Bell S, Weidert K, Gessessew A. Potential for Cost Recovery: Women's Willingness to Pay for Injectable Contraceptives in Tigray, Ethiopia. Vitzthum VJ, editor. PLoS One [Internet]. 2013 May 20 [cited 2019 Sep 27];8(5):e64032. Available from: https://dx.plos.org/10.1371/journal.pone.0064032 
41. Tamiru A, Tsegay G, Wubie M, Gedefaw M, Tomczyk S, Tekola-Ayele F. Podoconiosis patients' willingness to pay for treatment services in Northwest Ethiopia: potential for cost recovery. BioMed Cent Public Heal [Internet]. 2014 [cited 2019 Sep 27];14(1):254. Available from: http://biomedcentral.com/14712458/14/259

42. Kim S-Y, Sagiraju HKR, Russell LB, Sinha A. Willingness-To-Pay for Vaccines in Low- and Middle-Income Countries: A Systematic Review. Ann Vaccines Immun [Internet]. 2014 [cited 2019 Sep 24];1(1):1001. Available from: https://pdfs.semanticscholar.org/2a69/fced9d5e33eaa0862e473eb438c2f6ce2931.pdf

43. Noor Aizuddin A, Sulong S, Aljunid SM. Factors influencing willingness to pay for healthcare. BMC Public Health [Internet]. 2012 Nov 27 [cited 2019 Sep 27];12(S2):A37. Available from: https://bmcpublichealth.biomedcentral.com/articles/10.1186/1471-2458-12-S2-A37

44. Pavel MS, Chakrabarty S, Gow J. Assessing willingness to pay for health care quality improvements. BMC Health Serv Res [Internet]. 2015 Dec 1 [cited 2019 Sep 27];15(1):43. Available from: http://bmchealthservres.biomedcentral.com/articles/10.1186/s12913-015-0678-6

45. Muhammad R, Jamda M. Presbyopic correction coverage and barriers to the use of near vision spectacles in rural Abuja, Nigeria. Sub-Saharan African J Med. 2016;3(1):20.

46. Sharma G. Pros and cons of different sampling techniques. Int J Appl Res [Internet]. 2017 [cited 2019 Sep 29];3(7):749-52. Available from: http://www.allresearchjournal.com/archives/2017/vol3issue7/PartK/3-769-542.pdf

47. Biau DJ, Kernéis S, Porcher R. Statistics in brief: the importance of sample size in the planning and interpretation of medical research. Clin Orthop Relat Res [Internet]. 2008 Sep [cited 2019 Sep 29];466(9):2282-8. Available from: http://www.ncbi.nlm.nih.gov/pubmed/18566874

48. Nayak BK. Understanding the relevance of sample size calculation. Indian J Ophthalmol [Internet]. 2010 [cited 2019 Sep 29];58(6):469-70. Available from: http://www.ncbi.nlm.nih.gov/pubmed/20952828

49. Le Gall-Ely M. Definition, Measurement and Determinants of the Consumer's Willingness to Pay: A Critical Synthesis and Avenues for Further Research. Rech Appl en Mark (English Ed. 2009;24(2):91-112.

50. Meltzer ME, Congdon N, Kymes SM, Yan X, Lansingh VC, Sisay A, et al. Cost and expected visual effect of interventions to improve follow-up after cataract surgery prospective review of early cataract outcomes and grading (precog) study. JAMA Ophthalmol. 2017;135(2):85-94.

51. Horowitz JK. The Becker-DeGroot-Marschak mechanism is not necessarily incentive compatible, even for non-random goods. Econ Lett. 2006;93(1):6-11.

\section{Figures}


Records identified through the database search $(n=237)$
Additional records identified through other sources $(\mathrm{n}=15)$

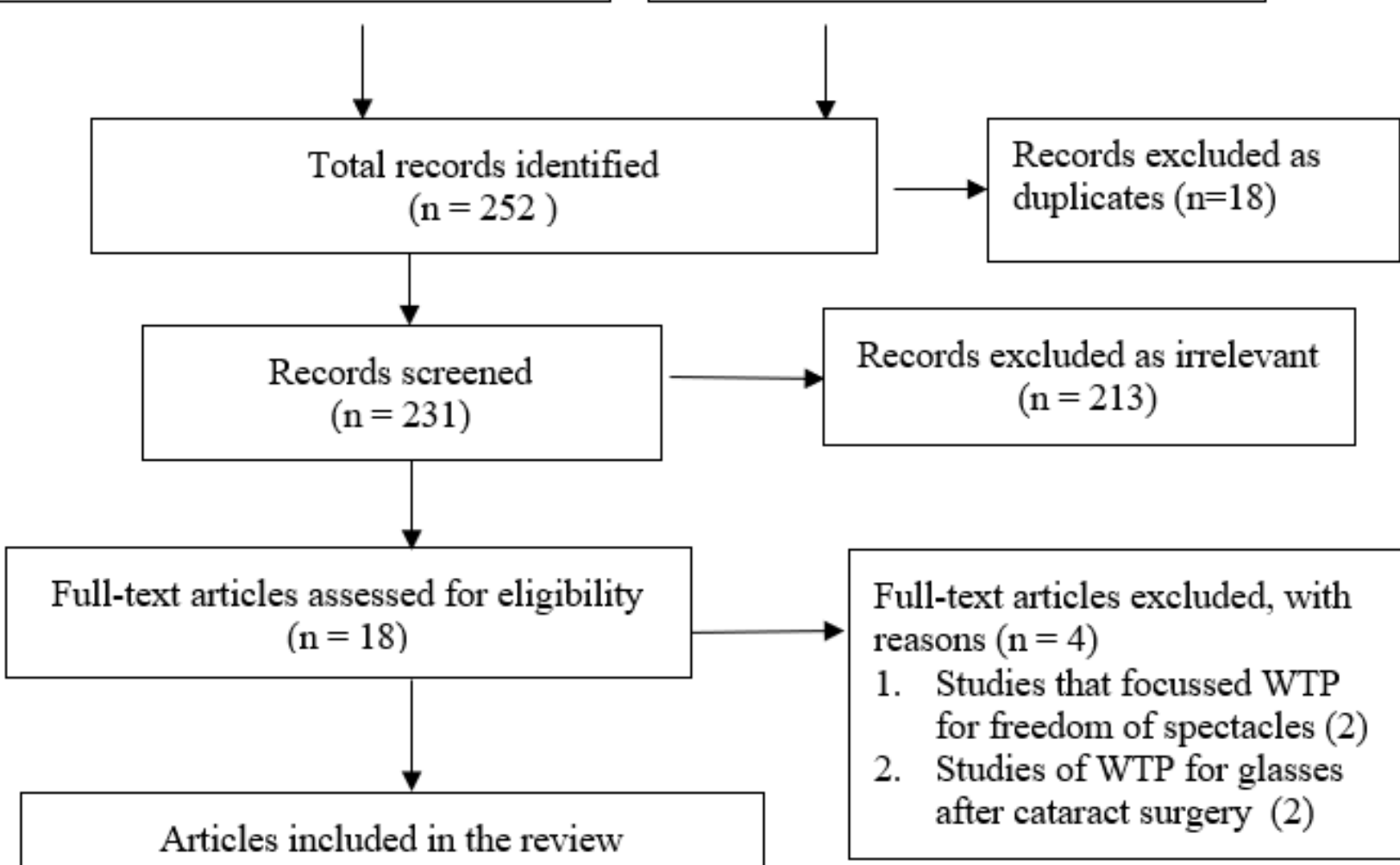

\section{Figure 1}

Flow chart of the process of search and selection of articles included in the review

\section{Supplementary Files}

This is a list of supplementary files associated with this preprint. Click to download.

- PRISMAWTPScopingReview.pdf

- WTPScopingReviewdata.docx 